\title{
Bridging Disciplines and Setting up Diverse Teams
}

\author{
Patricia Ann Marcellino \\ Adelphi University
}

\begin{abstract}
A qualitative action research study was conducted to explore whether an educational learning pattern inventory had application to teams in the MBA and educational leadership programs at a private university. Four courses were conducted by the same instructor. Fourteen teams were formed utilizing the inventory with 61 participants. Results illustrated that the inventory had value in both the business and education classroom in constructing diverse teams based on learning pattern theory. The inventory helped expedite the assignment of team roles and responsibilities and hastened team identity. Shared leadership emerged on the 14 teams in the study.
\end{abstract}

\section{Introduction and Background}

The literature on team and group-based cooperative models is voluminous with many descriptive narratives as well as empirical studies with primarily quantitative, and secondarily, qualitative methodological designs. Overall, empirical researchers have adopted a positivist/structuralist approach to team based and cooperative based research whether in the classroom or at the worksite. Most team research is quantitatively based and researchers intentionally limit variables. Researchers have measured multiple variables that affect achievement, performance, attitude or social interaction. But in spite of the abundance of empirical studies, there is no unified theoretical model of team development (Kline, 1999; Salas, Rozell, Mullen, \& Driskell, 1999) because teams by their very nature are multi-dimensional and complex. Because of this, there is ambiguity concerning what constitutes team research (DeMeuse \& Liebowitz, 1981; Kline, 1999). Moreover, because each researcher intentionally limits the number of variables in a study, some team studies seem to render an incomplete picture of teaming from the perspective of all participants.

According to Kline (1999), "there are so many theories about team performance, there are so many variables involved, and there are so many different ways to measure those variables that we are a long way from having a comprehensive theory of team performance" (p. 140). These complex variables may affect, influence or moderate the output of team units (Cohen \& Bailey, 1997; DeMeuse \& Liebowitz, 1981; Gully \& Devine, 1995; Johnson, Srinivasian, \& Kemelgor, 1998; Nowak, Miller, \& Washburn, 1996; Kline, 1999; Salas, Rozell, Mullen, \& Driskell, 1999; Springer, Stanne \& Donavan, 1999). It is recommended that teams conform to external criteria and be limited in size, develop rules and have clearly defined goals and performance outcomes (Bolman \& Deal, 1997; Katzenbach \& Smith, 2003; McKendall, 2000; Polzer, 2003; Swezey \& Salas, 1992). The role of the facilitator or instructor, communication feedback, time allotted, resources allocated, team and individual characteristics, skills and disposition of each team 
member may affect team output both positively and negatively (Katzenbach \& Smith, 2003; Kline, 1999).

Within the university classroom, teams are used to simulate the work experience and to develop team skills. In a management/leadership class, teams are usually task oriented and team members work toward achieving a desired output, performance, project or presentation, while they interact socially (Allie \& Beam, 1998; Bolton, 1999; Bowen, 1998; McCahon \& Lavelle, 1998; McKendall, 2000). Studies vary and measure a host of variables that affect team performance, such as team size (Bacon, Stewart, StewartBelle, 1998); the social network (Baldwin, Bedell, \& Johnson, 1997); the effect of cohesion including gender and team size (Gully \& Devine, 1995); as well as attitudes and time spent on team work (Freeman, 1996). Studies seem to range from a semester (Scudder \& Herschel, 1994) to a year (Freeman, 1996). Overall, in a majority of the studies reviewed, results were shown to be significant in regard to team performance and interaction.

Furthermore, there seems to be a difference in the use of teams in business class settings compared to the use of teams in educational class settings. The business team development model emphasizes the task, job or performance primarily (Katzenbach \& Smith, 2003; Kline, 1999), while the educational cooperative learning model seems to emphasize the development of values, such as cooperation, respect, tolerance and teamwork (Alavi, 1994; Antil, Jenkins, Wayne, \& Vadaxy, 1998; Crooks \& Klein, 1998; Hampton \& Grudnitski, 1996; Johnson \& Johnson, 1991, 1993, 1998, 1999; Johnson, Johnson, \& Maruyama, 1983; Kromrey \& Purdom, 1995; Ravenscroft \& Buckless, 1995; Slavin, 1977, 1999). According to Kline (1999), team members seem to work better when they are cooperating with one another. Senge (1990; 1994; et. al., 1999; et.al, 2000) maintained that team members should engage in constructive dialogue and influence one another to achieve team learning.

A team does not evolve simply because an instructor places adults into a group and labels them a "team." A study by Bolton (1999) showed that when 72 percent of faculty at a state university assigned students to project teams in at least one class, 81 percent of the students felt that faculty gave them no support. Faculties at the college were satisfied $(91 \%)$ with their team-building ventures, but students were less satisfied $(64 \%)$. Often, instructors do not intentionally formulate their class teams based on research constructed instruments. Class teams seem to be formed in a haphazard fashion. Some faculties leave the choice of team members to the students and have them formulate their own teams. Further research utilizing learning oriented team-based models and instruments particularly at the higher education level seems necessary.

Because of the impact of change on society, Drucker (1999) advocated knowledge of various learning models and learning theories so that future managers and leaders could adapt and develop understanding of themselves as continuous learners in regard to their own career development. In this regard, a learning inventory based on learning pattern theory may be well suited to the business and education classroom when setting up teams. Johnston $(1996,1998)$ approaches the team-based model from the perspective that by formulating teams based on diverse learning pattern theory, teams will work better and 
perform positively. Johnston's Interactive Learning Model (ILM) is a mind-brain connectionbased model, which uses a process (the Let Me Learn Process ${ }^{\circledR}$ ) to frame individual and group learning (Pearl, 2003). Johnston's ILM model is an original theoretical model that focuses on how the mind translates and formats information collected by the five senses.

Johnston posits that teams provide a multiplicity of intelligences and a diversity of learning patterns that become interconnected in the classroom whether students are elementary, secondary or adult learners. Johnston's theoretical framework rests on a foundation of constructs that can be traced to the interaction of the brain's operations and the mind's symbolic interpretation of those operations including: cognition (thinking), conation (processing) and affectation (feeling) capabilities. The interaction of these constructs manifests itself in four behavioral learning processes or patterns: Sequential, Precise, Technical and Confluent (Let Me Learn website: http://www.letmelearn.org).

Individual learners are represented by all four learning patterns and the interaction of each defines the learner and the approach to learning. The four learning patterns are defined as follows:

Sequential: the process of organizing, planning, seeking order and consistency;

Precise: the process of using information and words, detail-oriented, seeking confirmation of what is valid, right, and/or true;

Technical: the process of practical, active, autonomous problem-solving;

Confluent: the process of generating ideas, reading between the lines, and making connections, comfortable with taking risks, trying and failing and trying again, seeking to do it "my own way" (Silverberg, 2003).

Each learner utilizes the four patterns of sequential, precise, technical and confluent in different interactingcombinations. A maximum learning pattern score for each learning pattern is 35. Learners fall into three learning pattern ranges: "use first" (scores 25-35), "use as needed" (scores 17-24) or "avoid" (scores 7-16). A person's score is self administered on the Learning Connections Inventory@ $(\mathrm{LCl})$ developed by Johnston and Dainton (1997a). The LCl is a 28-item self report instrument with Likert scale (1-5) questions and three open-ended questions. The inventory incorporates Johnston's ILM and theoretical frame by assessing the interaction of the four learning patterns. The $\mathrm{LCl}$ quantitatively and qualitatively captures the degree to which an individual uses each of the four learning patterns (Pearle \& Head, 2002). See Table 1 for ILM Learning Pattern Characteristics in regard to cognition, conation and affectation. 

Table 1. The Interactive Learning Model (ILM)
ILM Learning Pattern Characteristics

\begin{tabular}{|c|c|c|c|}
\hline & Cognitively & Conatively & Affectively \\
\hline \multirow[t]{4}{*}{ Sequential } & Organizes information & Makes lists. & $\begin{array}{l}\text { Thrives on consistency and } \\
\text { dependability. }\end{array}$ \\
\hline & Mentally analyzes data. & Organizes. & $\begin{array}{l}\text { Needs things to be tidy and } \\
\text { organized. }\end{array}$ \\
\hline & Breaks tasks into steps. & Plans first, then acts. & $\begin{array}{l}\text { Feels frustrated when the } \\
\text { game plan keeps changing. }\end{array}$ \\
\hline & & & Feels frustrated when rushed. \\
\hline \multirow[t]{4}{*}{ Precise } & Researches information. & $\begin{array}{l}\text { Challenges statements } \\
\text { and ideas. }\end{array}$ & Thrives on knowledge. \\
\hline & Asks lots of questions. & $\begin{array}{l}\text { Documents research and } \\
\text { findings. }\end{array}$ & Feels good when correct. \\
\hline & Wants to know more. & Writes things down. & $\begin{array}{l}\text { Feels frustrated when } \\
\text { incorrect information is } \\
\text { accepted as valid. }\end{array}$ \\
\hline & & $\begin{array}{l}\text { Writes long e-mail } \\
\text { messages and leaves } \\
\text { long voice mail } \\
\text { messages. }\end{array}$ & $\begin{array}{l}\text { Feels frustrated when people } \\
\text { do not share information. }\end{array}$ \\
\hline \multirow[t]{4}{*}{ Technical } & $\begin{array}{l}\text { Seeks concrete real world } \\
\text { relevance. }\end{array}$ & Hands on. & $\begin{array}{l}\text { Enjoys knowing how things } \\
\text { work. }\end{array}$ \\
\hline & $\begin{array}{l}\text { Only wants information as } \\
\text { needed - nothing } \\
\text { extraneous. }\end{array}$ & Tinkers. & Self-sufficiency feels good. \\
\hline & & Solves the problem. & $\begin{array}{l}\text { Feels frustrated when a task } \\
\text { has no real world relevancy. }\end{array}$ \\
\hline & & & $\begin{array}{l}\text { Enjoys knowing things, but } \\
\text { doesn't need to share } \\
\text { information. }\end{array}$ \\
\hline \multirow[t]{6}{*}{ Confluent } & Reads between the lines. & Takes risks. & Enjoys energy. \\
\hline & Thinks outside the box. & Not afraid to fail. & Feels comfortable with failure. \\
\hline & Brainstorms. & Talks about things a lot. & $\begin{array}{l}\text { Does not enjoy having ideas } \\
\text { criticized. }\end{array}$ \\
\hline & $\begin{array}{l}\text { Makes obscure } \\
\text { connections between } \\
\text { things that are seemingly } \\
\text { unrelated. }\end{array}$ & $\begin{array}{l}\text { Might start things and not } \\
\text { finish them. }\end{array}$ & $\begin{array}{l}\text { Frustrated by people who are } \\
\text { not open to new ideas. }\end{array}$ \\
\hline & & $\begin{array}{l}\text { Starts a task before } \\
\text { directions are given. }\end{array}$ & Enjoys a challenge. \\
\hline & & & $\begin{array}{l}\text { Feels frustrated by repeating } \\
\text { a task over and over. }\end{array}$ \\
\hline
\end{tabular}

Model adapted from Let Me Learn Process ${ }^{\circledR}$ Christine A. Johnston Proceedings of the 2003 American Educational Research Association, Chicago, II., April 21-25, 2003. Copyright $@ 2001$, Let Me Learn, Inc. 
Nationally and internationally validated, the LCI has test-retest reliability (Learning Connections Resources Website: http://www.LCRinfo.com) as well as content, construct, and predictive validity (Johnston \& Dainton, 1997b). After the LCl is administered, the instructor continues to monitor the interaction of the learning patterns as the class evolves. LCl inventory scores are shared among class and team members. Learning patterns are demonstrated through a series of tasks based on Johnston's ILM. If team problems develop, it is suggested that the instructor guide and coach team members to investigate the differences in their learning patterns as a possible source of team tensions. Rather than being considered a passive recipient of information, the learner takes control of making learning work and for co-constructing knowledge (Pearle \& Head, 2002). The ILM assumes that if an individual knows his or her set of integrated learning patterns, he/she can use that knowledge to attend to the learning task. The learner takes responsibility for making the learning work. According to Pearle (2003), the conceptualization moves from the internal mental functions and operations of the individual to the external world of social operations within a teachinglearning context.

\section{Problem}

Adults have various assumptions that affect their behaviors and how they interact in team units. Because of this, adults may experience a tension when they serve on a team (Katzenbach \& Smith, 2003; Kling, 2000; Lipnack \& Stamps, 1997; Pacanowsky, 1995; Senge, 1990; Thompson, 2000), which may become problematic for team units. This dilemma seems inherently part of the team process and seems to influence any shift toward or away from team units (Thompson, 2000). How each adult individual reconciles this tension seems to determine whether the adult may learn from the team experience. The problem for an instructor working with teams in the classroom setting is how to construct class teams so that team tensions are eased and students identify with their teams.

\section{Purpose}

Four management/leadership courses were conducted by the same instructor to explore whether a research-based learning inventory developed by Johnston \& Dainton (1997a; $1997 \mathrm{~b}$ ) could be utilized in formulating diverse teams in the business management and educational leadership classroom. Two courses were conducted in the MBA program and two were conducted in the educational leadership program. Fourteen teams were formed. The business classes were composed of 33 managers and aspiring leaders and the education classes were composed of 28 teachers and aspiring principals. The two business courses were conducted first, then the two education courses were conducted. 


\section{Research Design}

Applying a qualitative design to this study seemed to provide a broader and deeper investigation of what was happening to all students as they interacted in their teams. Rushmer (1997) advocated qualitative measures in working with team-based units so as to provide a deeper analysis from multiple perspectives. Action research or putting theory into action in the classroom builds on the qualitative approach (Bogdan \& Biklen, 1998; Mills, 2003). An instructor conducts it directly in the classroom in order to improve teaching and learning and to close the gap between theory and practice (Mills, 2003). According to Mills (2003), human beings "are very complicated organisms, and compared with chemicals - and mice, for that matter - their behavior can be disorderly and fairly unpredictable. This presents a challenge to educational researchers, who are concerned with gaining insight into human behavior in educational environments such as schools and classrooms (p. 3)."

Within the action research model, the instructor engages in a cycle of reflection, discussion, re-thinking, re-planning, understanding and learning (Mills, 2003). Mills advised conducting research in four broad stages: 1) focusing on a topic (in this study, the application of a learning inventory to develop team units), 2) collecting data, 3) analyzing the data, and 4) formulating a new "action plan." In this regard, the new action plan is the redesign of a course syllabus. Words, rather than numbers, are the primary units of measurement in qualitative research, but within the action research model, quantitative instruments, such as surveys and inventories may also be utilized. Because the investigation of teams can be unwieldy, Miles \& Huberman's (1994) structured qualitative guidelines were applied to the data analysis. Mills (2003) and Miles \& Huberman (1994) were complimentary.

\section{Participants}

The researcher investigated 14 teams comprised of 61 adults. There were seven business teams and seven education teams. In the MBA program, there were five teams of five members and two teams of four members. In the educational leadership classes, there was one team of five members, five teams of four members and one team of three members. There were 40 females and 21 males participating in the 14 teams. The females (16) and males (17) were evenly divided in the business classes across teams. In the education classes, there were more females (24) participating than males (4). Because of a larger representation of female students in the education courses, there were two all female teams in the education classes. See Table 2 for a Comparison of the Team Make-up in the Business and Education Classes. 
Table 2: A Comparison of the Team Make-up in Business and Education Classes

\begin{tabular}{|l|c|c|c|c|c|}
\hline & Business & Business & Education & Education & Totals \\
& Class 1 & Class 2 & Class 1 & Class 2 & 4 \\
\hline Participants & 19 & 14 & 17 & 11 & 61 \\
\hline Teams: & 4 & 3 & 4 & 3 & 14 \\
& $\begin{array}{l}\text { 5; teams of } \\
\text { of 4. }\end{array}$ & $\begin{array}{l}2 \text { teams } \\
\text { of 5; 1 } \\
\text { team of 4. }\end{array}$ & $\begin{array}{l}\text { 3 teams of } 1 \text { team } \\
\text { of 5. }\end{array}$ & $\begin{array}{l}\text { 2 teams } \\
\text { of 4; 1 } \\
\text { team of 3. }\end{array}$ & \\
\hline Females & 9 & 7 & 15 & 9 & 40 \\
\hline Males & 10 & 7 & 2 & 2 & 21 \\
\hline
\end{tabular}

Polzer (2003) and Thompson (2000) advise setting up diverse teams to enhance creativity and problem-solving. Johnston posits that diverse teams should be composed of individuals representing each of the four "use first" learning patterns and that these learning patterns should be represented across teams. Aspects of Johnston's interactive learning process were demonstrated before students took the $\mathrm{LCl}$. Students were invited to visit the website (Let Me Learn website: http://www.letmelearn.org). The class means and team means of each learning pattern were compiled as adults who represented each of the four learning patterns were placed and balanced across the 14 teams. If someone avoided a learning pattern, they were placed with individuals who led by that learning pattern so that each learning pattern was represented across teams. Class and team members' learning pattern scores were shared.

Strong willed learners (SWL) are learners who use three or more learning patterns at the "use first" level. Their scores are 25 and over in these patterns. Team members sometimes have problems relating to SWL because their learning patterns are not easily identified. They can easily switch their lead learning patterns demonstrating different patterns initially, which is sometimes confusing to team members. SWL may also be problematic on teams because they may try to control other team members or they may withdraw from the team process altogether becoming a "one person team" and preferring to work alone (Pearle, 2003). It should be noted that Johnston (2001) advises placing SWL on a separate team of four or more to minimize SWL domination of a team. The instructor, however, preferred not to create SWL teams because the goal in each course was to maintain team member interaction toward a common interconnected purpose rather than have SWL working separately under their team umbrella.

There were 19 SWL among the 61 participants. The business classes had six (out of 19) SWL in the first class and six (out of 14) in the second class. The first education class had five (out of 17) SWL, while the second education class had two. In all classes, SWL were distributed across teams, rather than confined to one team. In 
addition, students may be characterized as bridge learners. Bridge learners are fairly balanced in their scores with ranges between 19 and 25 (use as needed) across all four patterns. On teams, bridge learners seem to provide dependability and consistency. When possible, bridge learners were placed on teams with SWL in order to provide steadiness to a team. See Table 3 for a Distribution of SWL and Bridge Learners on Teams.

Table 3: Distribution of SWL and Bridge Learners on Teams

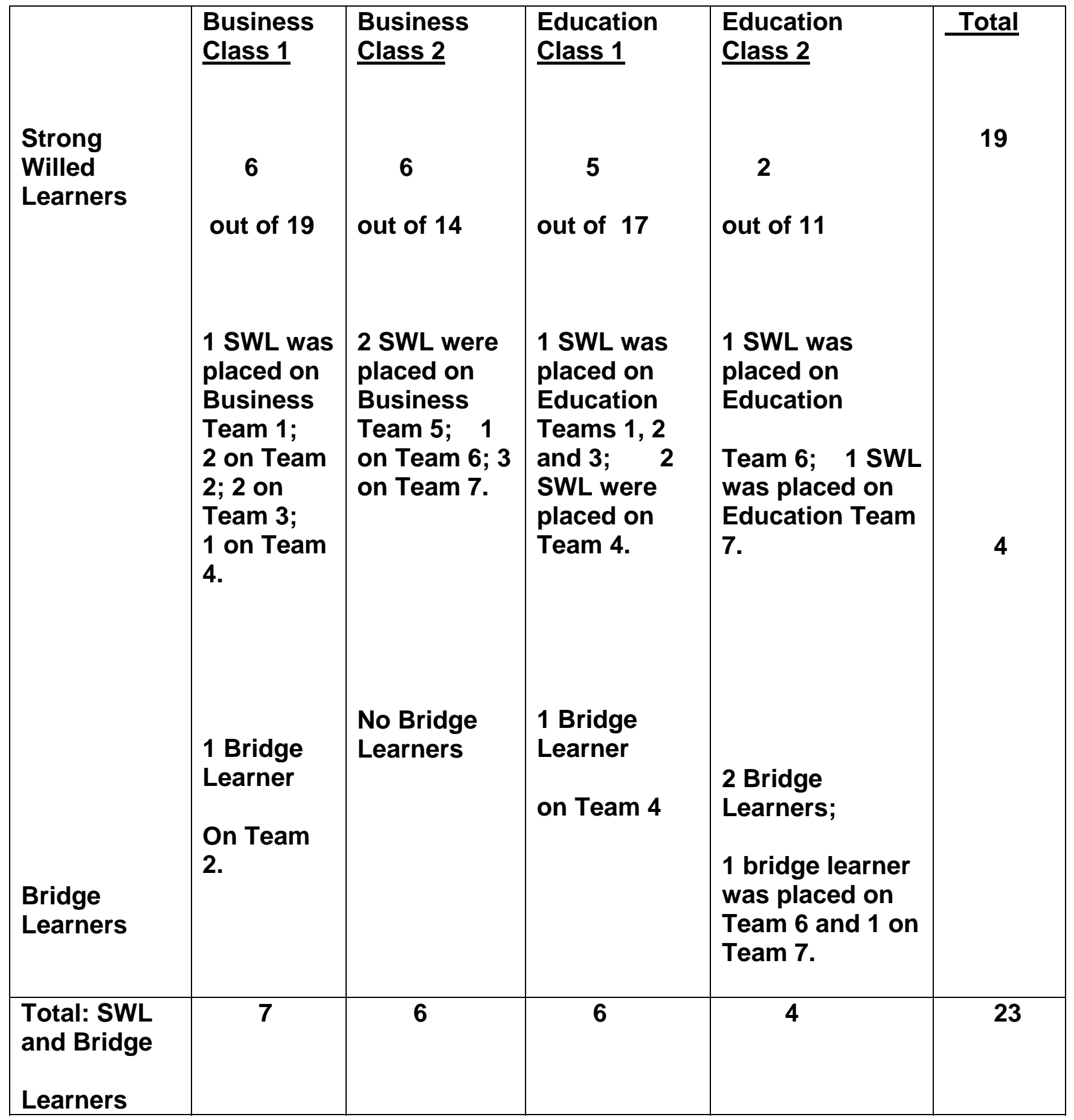




\section{Methods and Data Collection}

The instructor was the action researcher, but each graduate student was also an action researcher as each adult participated in the action research process (Mills, 2003). Each team was asked to complete a project task, which included one team policy paper and an extensive technological team presentation with peer evaluation (Topping, 1998). Students were also asked to investigate their team process from an individual perspective, while producing their team projects from a team perspective. Methods were triangulated to provide trustworthiness of the data in regard to credibility and dependability. These methods included updates from participants through e-mail and in-person (these were tracked and coded). Additional comparative methods included evaluative questionnaires at strategic points and students' individual summative team process reflective critiques. These methods became the data sources and enabled multiple team perspectives and team stories to be constructed.

Data was collected, chronicled and analyzed for themes, patterns, actions, events and surprises (Miles \& Huberman, 1994). These various methods enabled the instructor and researcher to collect multiple perspectives from team members regarding the use of the $\mathrm{LCl}$ and learning pattern identification on each team. Students' words were compared, contrasted and analyzed. After the data was collected, a categorization process was established and a coding system was generated.

Categories and sub-categories were created based on the number of participants who mentioned a theme or pattern, the uniqueness of the information and whether the information was applicable to team units. The process of categorizing the data was repeated several times in order to refine the analysis. Overall, the dependability of the data was supported by the credibility of the "words" of the participants. While there were many questions asked, one overall question was: Can learning pattern theory be utilized by the instructor and adult students in constructing teams in business and education courses?

\section{Results and Findings}

The purpose of this action-research study was to conduct an investigation of 14 teams in four management/leadership courses as 61adults engaged in experiential action research and applied an inventory instrument (LCI) and an educational model (ILM) to team units. In regard to the question: Can learning pattern theory be utilized by the instructor and adult students in constructing teams in business and education courses? Results illustrated that the learning inventory had value in both the business and education classroom when setting up teams. The $\mathrm{LCl}$ was a worthwhile tool to utilize in setting up diverse teams in the classroom setting regardless of the discipline. Students and instructor benefited. The inventory helped expedite the assignment of team roles and responsibilities and hastened team identity by enabling the students in the business classes and the instructor in the education classes to initially suggest team roles consistent with team members' leading or primary learning patterns. 
Each team completed a project task, which included a team policy paper and an extensive technological team presentation with peer evaluation (Topping, 1998). Findings indicated that students gained experience in producing an external team product, and gained experience in the internal process of team development including interacting with diverse people who represented various learning patterns. Team members developed self-awareness of their own learning patterns and then an awareness of their team members' learning patterns. In both the business and education classes, students assumed roles within their teams that were consistent with their learning patterns. In the first business class, students assigned these roles, while in the second business class, the team roles that emerged or were assumed by the students were consistent with the leading learning patterns of the team members. One business team member stated:

-My team wanted to test the inventory and see if it was accurate so we assigned people to jobs according to their scores (Business/Team 1).

These team roles corresponded to students' learning patterns, for example, sequential learners became the team organizers, schedulers or recorders; precise learners became the team communicators, researchers, editors and writers; technical learners became the problem solvers, analyzers, and technicians; and confluent learners became the idea-generators, challengers, risk-takers and emcees. Because education students utilized the jigsaw model of cooperative education theory in their own classrooms and seemed to gravitate toward working on separate functions initially rather than coming together as a unified team, the instructor (following the lead of her business students) suggested the adoption of initial team roles in order to expedite a unified structural team formation. Because education students utilize various learning models within the education discipline, there seemed to be an initial hesitation in adopting the business team model recommended. Therefore, to prevent hesitation and confusion, the instructor suggested initial team roles to members on the education teams. As the team process continued to evolve on the education teams, education students continued to identify with these team roles seemingly to prefer them on their teams. An education team member stated:

-Before taking this course, I thought of the team process as cooperative groups or just simply a group of people (small or large) working under the same title. However, now I know that a team must have a common purpose and hold themselves mutually accountable (Education/Team 1).

Usage of the $\mathrm{LCl}$ with its reflective practice base seemed to increase the instructor's understanding of students in regard to their learning patterns. The application of the $\mathrm{LCl}$ enabled the instructor to build relationships with them by appealing to their learning patterns. The instructor implemented various tasks and demonstrations recommended by Johnston so that team members could develop a basic understanding of learning pattern theory. As each class iteration evolved, the instructor was able to further her craft as a practitioner and action researcher and gain experience as an external facilitator and coach to the teams. As an external facilitator and coach, the instructor 
tried to ease individual/team tensions by helping students to focus on their learning pattern differences.

Tensions emerged on both the business and education teams. This was especially surprising in the education classes because students seemed to be acculturated toward a cooperative, collaborative and relationship-building model. When tensions emerged, the instructor coached students to reflect on their team assumptions and analyze their team tensions from a different perspective, one that was based on self-reflection and tolerance for learning pattern differences. The easing of team tensions encouraged students to continue to work within their teams and focused team members on team cohesion and unity.

The LCl helped expedite the assignment of initial team roles and responsibilities by enabling the students and the instructor to initially suggest team roles consistent with team members' leading learning patterns. By initially suggesting team roles, students began to share in the team leadership role and shared leadership continued to evolve on all 14 teams. Contrary to guidelines provided by Katzenbach and Smith (2003), the role of team leader was not assumed on any team. Instead, shared leadership and shared responsibilities evolved. This sharing of the leadership function was likely a byproduct of assigning initial team roles from the onset. By suggesting team roles, team identification seemed to hasten as students began to assume the responsibilities of their roles in regard to team tasks. By sharing responsibilities and sharing leadership, team members were able to achieve the goals they laid out for their teams.

\section{Discussion}

Themes and patterns emerged that were consistent in the business and education classes. Class participants $(n=61)$ applied the $\mathrm{LCl}$ on a personal level primarily, and then participants attempted to utilize its precepts in developing an understanding of their team members. Team roles were consistent with the primary or leading learning patterns of individual students on the teams. Shared leadership emerged on all 14 teams. Initial team roles were assigned by the students themselves (business classes) or suggested by the instructor (education classes) according to the four learning pattern preferences indicated in the LCl. The ILM and LCl were intentionally applied by the instructor so as to give teams and team members a focus that was learning related.

\section{Theme: Adapting Learning Pattern Theory and Learning Pattern Terminology}

In both the business and education teams, students began to describe themselves in terms of learning pattern theory. Students also described team members and their interactions with them in regard to the $\mathrm{LCl}$ and learning pattern theory. Through the use of the $\mathrm{LCl}$, students indicated that they came to understand their own learning patterns first and then tried to develop an understanding of their team members according to their learning patterns. Students began to approach their team members on the basis of their learning patterns. Comments from business and education team members were similar in their basic understanding of the learning patterns in regard to themselves and their team members. Their comments indicated that they related to one another on the 
basis of their learning patterns and gained an understanding of one another that was learning related. For example, team members stated:

Business/Team 2: [The LCI] made me understand myself better, which will ultimately help in the way I interact with people.

Education/Team 3: I came to an understanding of my learning pattern that will make me aware of how I work and learn.

Business/Team 3: Because of our learning patterns, we understood ourselves and then we understood each other.

Education/Team 4: I was able to understand the behavior of my team members at times because of their learning patterns.

Business/Team 5: I am a SWL, but may be too much so that I over extend myself constantly.

Education/Team 7: Since I am a bridge learner, I dabble consistently in all the learning patterns.

Business and education students also noted how they interacted with and complemented one another based on their learning patterns. Students in both disciplines noted how the interactions of their learning patterns enhanced the work of the team. Comments from business and education team members Included the following:

Business/Team 1: I think my scores were accurate and they confirmed my team's scores.

Business/Team 4: My team mate and I had complimentary learning patterns. We worked closely together and enhanced one another's work. She is highly precise and I am highly confluent. I was only concerned about the big picture effects, but she was concerned about the details. With her, my work became better.

Business/Team 5: Our [learning pattern] skills complemented each other well and everyone brought something different to the team.

Business/Team 6: Two of my team members were precise. One member was so precise that in our presentation; she had the photos change according to the rhythm of the music. It was timed so precisely.

Business/Team 7: The $L C l$ described me perfectly. I am sequential and precise. As teammates, we worked closely together; they were more technical and confluent. I can see where it would be beneficial for managers to know the learning patterns of employees so they can match employees up on projects. 
Education/ Team 1: Because of one member's high confluence and skill in technology, we took our team in that direction. Another member was a SWL and needed to be involved in all aspects of the project [so] I made sure I updated her most often. Because of my precision, I took on the role of editor and communicator.

Education/Team 2: Those precise people can truly drive you crazy. Nothing can be out of place. On the other hand, the creative ones [on the team] allowed the group to interact and have fun.

Education/Team 3: One team member let her creativity take over and moved our team in that direction. Another provided the detail work and problem solved throughout. I was sequential and as a team, we worked very well together.

Education/Team 5: We were conscious of the fact that as a team our confluent patterns necessitated more sequential and precise strategies to bring us together and we did it.

Education/Team 7: We had the correct mix of learning patterns on our team. We interacted and balanced one another's traits. Every one of us strongly identified with this team.

\section{Theme: Shared Leadership Emerges On Business and Education Teams}

Team members agreed that they did not have a designated leader, but instead on 14 teams adults shared leadership on their teams. The utilization of the $\mathrm{LCl}$ in suggesting initial team roles within their teams aided the team structural foundation. It seemed to expedite identification to the team as each person initially assumed team responsibilities by performing a role on the team. The sharing of team roles lessened the need for a team leader and may have been the reason why "one leader" was not needed.

Students seemed to deliberately pull back on leading their teams and did not assume "the leader" role. This was true of SWL as well. As teams evolved, responsibilities and leadership continued to be shared. The concept of shared leadership is an emerging topic for academic research; in the past, leadership research has focused primarily on one individual as leader within a team and not on leadership as a shared process (Pearce \& Conger, 2003). Students in business and education teams made the following comments:

Business/Team 1: I was categorized as a SWL and I didn't want to take control of the group. I didn't want to be the leader because I had that label - SWL. I didn't like the label. My team members agreed that I did not lead or control the team. Instead, [except for one team member] we all shared the leadership role. 
Business/Team 3: The strength of this team was the willingness of every team member to take on responsibilities. Everyone was quick to step forward to do whatever was necessary to reach our goal...there was a lack of egos.

Business/Team 3: We had no leader, everybody had an equal part. I've been on other teams and there's usually one person who wants to be the leader and control the team, but in our team, we all shared.

Business/Team 4: Our team never really chose a leader; we were instead trying to coexist equally. We all played a part in leading this team.

Business/Team 5: I don't think one leader was necessary. We each carried the team . .. and let others take over when we didn't have knowledge of that area. Normally I will become the organizer and meeting task coordinator. However, when I do this, I end up doing a large percentage of work. Others know I won't let the task not get completed, so they let me do it. With this group, I did what was expected of me and watched to make sure that one person wasn't carrying the bulk of the work.

Business/Team 6: We didn't have one leader. We were all leaders sharing in decisions and contributing our talents and skills on different aspects of this project.

Business/Team 7: We really came together as a team. In the final analysis, we all shared leadership.

Similar statements comparable to business team members were also attributable to education team members as they analyzed the team process on their teams.

Education/Team 1: Everyone on our team played a role and no role was more important than any other. We were all leaders within this team.

Education/Team 2: Leadership was shared on the basis of the collective skills within the group.

Education/Team 3: I deliberately held back and let my team mates take over. They took this team in a direction that I would never have taken it if I were acting alone or if I was the leader. We shared in the leadership role.

Education/Team 4: Not one of us was the leader, but we led each other.

Education/Team 5: We merged our talents and skills and shared leadership on our team.

Education/Team 6: There were times when we each acted as leaders. We all became leaders at different times using our strengths. We did not have one leader. 
Education/Team 7: I haven't really been on a team that was assembled by someone else, without my input. We shared the leadership role, brought varied experiences to the table and managed to assemble a great piece of work.

\section{$\underline{\text { Team Surprises and Contrasts }}$}

Because methods were triangulated and included updates from participants through email and in-person, which were tracked and coded, the instructor and action researcher was able to track the tensions on the teams. These tensions led to team member withdrawal on four teams. Team member withdrawal was experienced by two of the teams in business (Teams 1 and 2) and two of the teams in education (Teams 3 and 4). This was a surprising revelation. In these cases, the "team" members were not able to develop an awareness of their team members' learning patterns because their interaction with team members was limited. All students were in management/leadership courses attempting to advance their careers into leadership positions in corporations or schools. Their withdrawal from the team process was a surprise to their team members and this seemed to affect the satisfaction of the remaining team members on these teams. Team products were not affected as the other students on the team worked around and made up for individual team member withdrawal. Remaining team members shared leadership roles in spite of the withdrawal of a team member.

Although these individuals withdrew at times from their team units, they developed selfawareness of their own learning patterns. The students on the business teams attributed their withdrawal to a difference in learning patterns (Team 1) and a conflict with a SWL (Team 2).

Business/Team 1: Annoyance is what I felt . . .l am a technical learner and people on this team were too sequential for me.

Business/Team 2: My work made the team project better, but [one team member], a SWL, was overpowering and wanted things her way.

Two students on education teams (Teams 3 and 4) withdrew because of a lack of role identification on their teams. Because of a duplication of learning patterns, team roles on these teams were shared with other team members and were not clearly defined. In spite of the presence of bridge learners on Business/Team 2 and Education/Team 4, tensions on teams were not eased. Learning pattern terminology was utilized by education team members to describe their difficulties with team members.

Education/Team 3: My team member, a SWL, and I shared team roles. Because of this, I was confused about my role on this team.

Education/Team 4: There were five members on this team. Even though I was a $S W L$, I was unable to impact the team's performance. I had no major role on this team so I withdrew. 


\section{Conclusions and Implications}

This study applied an educational model (ILM) and learning instrument (LCI) to 14 teams in four management/leadership courses. Two courses were in the MBA program and two courses were in an educational leadership program. Based on results and findings, the $\mathrm{LCl}$ had value in business and education in formulating teams and hastening the team structural foundation by assigning team roles and responsibilities consistent with students' leading learning patterns. Use of the LCl helped identify team roles. Students were able to identify with their teams based on this early role formulation. The formulation of teams based on learning pattern theory gave teams an initial central focus that strengthened and expedited the team structural foundation.

The modal team size is usually five members (Thompson, 2000). Based on this study, however, it is recommended that teams have no more than four members when assigning roles based on the $\mathrm{LCl}$ and learning pattern preferences. Everyone on a team should have a clear and distinguishable role on the team. When utilizing the $\mathrm{LCl}$ to formulate teams, having four member teams may lessen the role confusion that members on the education teams experienced. It is also suggested that SWL be placed across teams and given an initial or suggested role consistent with their highest primary pattern; this may lessen SWL control or withdrawal of team members from the team. Even though Johnston (2001) advises placing SWL on separate teams of four or more to minimize domination of a team, in this study, most SWL did not attempt to control their teams.

By following the action-research cycle presented by Mills (2003), the instructor was able to redesign her syllabus or "action plan" in regard to her understanding of the LCl and learning pattern theory as it applied to diverse team units. Some of her proposed changes to her syllabus were to: 1) formulate teams composed of four learners so that team roles could be consistent with learning patterns, 2) distribute SWL and suggest a role for each of them so that they do not attempt to "control" their teams or alienate themselves from their teams, 3) distribute bridge learners (if possible) on teams with SWL to offset their dominance, 4)) suggest that each team rotate an internal team facilitator within each team. While the instructor remains an external facilitator to each team, the instructor is not a member of each team, therefore, an internal facilitator would support the team and also try to reduce team tensions if they arise, and 5) the instructor should continue to ask for updates from all team members so as to monitor team tensions externally and continue to coach students through these tensions by referring to their learning pattern differences. By coaching students, tolerance of learning pattern differences might be learned.

The LCl engaged adult learners in developing self-awareness and a beginning awareness about team members in regard to their learning patterns. The application of a learning instrument that focuses on learning pattern theory may help management and educational professionals increase their team learning skills by working through their team differences. It is conceivable that the application of the $\mathrm{LCl}$ may be widened to other disciplines as well and might also be applied at worksites. Perhaps, the LCl will 
encourage adults to focus on their learning pattern differences rather than on their cultural, age, gender, race or ethnic differences.

While the LCl did enable students to broaden their understanding of their own learning, as an instrument to further team member interactions and building team member understanding, more time and research is needed. Continuing research is also recommended regarding the emerging concept of shared leadership (Pearce \& Conger, 2003). Moreover, it should be noted that if a researcher were to compare multiple intelligence theory (Gardner, 1983) to learning pattern theory, the researcher would have to note that multiple intelligence theory is a cognitive based model, primarily; it does not address the constructs of affectation or conation. In addition, the LCl is not a personality or behavioral inventory and further research would also be needed regarding the correlation of a personality instrument, such as the Myers-Briggs inventory (Leonard \& Straus, 1997) or a Learning Styles inventory (Kolb, 1984) with the $\mathrm{LCl}$.

\section{Research Significance}

Instructors and facilitators may formulate teams on the university level by structuring teams utilizing the LCl. The application of a learning instrument that focuses on learning pattern theory will help business and educational professionals as aspiring leaders increase their self-awareness and their awareness of their team members. Utilization of the LCl may strengthen team formation by hastening team role identification. Furthermore, this study may aid instructors in developing their own action research team instructional models so that their adult students may develop their team and leadership skills and experiences through the application of learning pattern theory. 


\section{REFERENCES}

Alavi, M. (1994). Computer mediated collaborative learning: An empirical evaluation. MIS Quarterly, I8 (2), 159-175.

Allie, R.E., \& Beam, H.H. (1998). The use of teams in an undergraduate management course. Journal of Management Education, 22 (6), 707-720.

Antil, L.R., Jenkins, J.R., Wayne, S.K., \& Vadasy, P.F. (1998). Cooperative learning: Prevalence, conceptualizations, and the relation between research and practice. American Educational Research Journal, 35 (3), 419-454.

Bacon, D.R., Stewart, K.A., \& Stewart-Belle, S. (1998). Exploring predictors of student team project performance. Journal of Marketing Education, 20 (1), 63-72.

Baldwin, T.T., Bedell, M.D., \& Johnson, J.L. (1997). The social fabric of a teambased MBA program: Network effects on student satisfaction and performance. Academy of Management Journal, 40 (6), 1369-1397.

Bogdan, R.C., \& Biklen, S.K. (1998). Qualitative research in education. Needham Heights, MA: Allan \& Bacon.

Bolman, L.G., \& Deal, T.E. (1997). Reframing organizations. San Francisco, CA: Jossey-Bass, Inc.

Bolton, M.K. (1999). The role of coaching in student teams. Journal of Management Education, 23 (3), 233-251.

Bowen, D.D. (1998). Team frames: The multiple realities of the team. Journal of Management Education, 22 (1), 95-104.

Cohen, S. G., \& Bailey, D.E. (1997). What makes team work: Group effectiveness research from the shop floor to the executive suite. Journal of Management Education, $\underline{23}$ (3), 239-291.

Crooks, S.M., \& Klein, J.D. (1998). Effects of cooperative and individualized learning during learner controlled computer based instruction. Journal of Experiential Education, 66 (3), 223-255.

DeMeuse, K.P., \& Liebowitz, S.J. (1981). An empirical analysis of team-building research. Group \& Organizational Studies,6 (3), 357-378.

Drucker, P.F. (1999). Management challenges for the $21^{\text {st }}$ century. New York: Harper Collins.

Freeman, K.A. (1996). Attitudes toward work in project groups as predictors of academic performance. Small Group Research, 27 (2), 265-285. 
Gardner, H. (1983). Frames of mind. New York: Basic Books.

Gully, S.M., \& Devine, D.J. (1995). A meta-analysis of cohesion and performance. Small Group Research, 26 (4), 497-521.

Hampton, D., \& Grudnitski, G. (1996). Does cooperative learning mean equal learning? Journal of Education for Business, 72 (1), 5-8.

Johnson, D.W., \& Johnson, R.T. (1991). The impact of positive goal and resource interdependence on achievement, interaction, and attitudes. Journal of General Psychology, 118 (4), 341-343.

Johnson, D.W., \& Johnson, R.T. (1993). Impact of cooperative and individualistic learning on high-ability students' achievement, self-esteem, and social acceptance. Journal of Social Psychology, 133 (6), 839-845.

Johnson, D.W., \& Johnson, R.T. (1998). Cooperative learning returns to college. Change, 30 (4), 26-36.

Johnson, D.W., \& Johnson, R.T. (1999). Making cooperative learning work. Theory into practice, 38 (2), 67-74.

Johnson, D.W., Johnson, R.T., and Maruyama, G. (1983). Interdependence and interpersonal attraction among heterogeneous and homogeneous individuals a theoretical formulation and a meta-analysis of the research. Review of Educational Research, 53 (1), 5-54.

Johnson, S., Srinivasan,,S., \& Kemelgor, B. (1998). Organizational structure and The role of empowered teams. Journal of Education for Business, 73 (5), 280-283.

Johnston, C.A. (1996). Unlocking the will to learn. Thousand Oaks, CA: Corwin Press, Inc.

Johnston, C.A. (1998). Let me learn. Thousand Oaks, CA: Corwin Press, Inc.

Johnston, C.A. (2001). Successful team building: The result of an advanced learning approach. Center for the Advancement of Learning, Rowan University, unpublished.

Johnston, C. A., \& Dainton, G.R. (1997a). The learning connections inventory. Pittsgrove, NJ: Learning Connections Resources, LLC.

Johnston, C..A., \& Dainton, G. R. (1997b). Learning connections inventory users' manual. Pittsgrove, NJ: Learning Connections Resources, LLC. 
Katzenbach, J. R., \& Smith, D.K. (2003). The wisdom of teams. Boston, MA: Harper Business.

Kline, T. (1999). Remaking teams: The revolutionary research-based guide that puts theory into practice. San Francisco, CA: Jossey-Bass, Inc.

Kling, J. (2000, July). Tension in teams. Harvard Management Communication Letter. Harvard Business School Publishing, Article reprint \#C0007A.

Kolb, D.A. (1984). Experiential learning: Experience as the source of learning and development. Englewood Cliffs, NJ: Prentice-Hall, Inc.

Kromrey, J.D., \& Purdom, D. M. (1995). A comparison of lecture, cooperative learning and programmed instruction at the college level. Studies in Higher Education, 20 (3), 341-350.

Leonard, D., \& Straus, S. (1997). Putting your company's whole brain to work. Harvard Business Review, 75 (4), 111-126. Reprint \#97407.

Learning Connections Resources Website: http://www.LCRinfo.com.

Let Me Learn Website: http://www.letmelearn.org.

Lipnack, J., \& Stamp, J. (1997). Virtual teams. New York: John Wiley \& Sons, Inc.

McCahon, C.S., \& Lavelle, J.P. (1998). Implementation of cross-disciplinary teams of business and engineering students for quality improvement projects. Journal of Education for Business, 73 (3) 150-157.

McKendall, M. (2000). Teaching groups to become teams. Journal of Education for Business, 75 (5), 277-282.

Miles, M.B., \& Huberman, A.M. (1994). Qualitative data analysis. Thousand Oaks, CA: Sage Publications.

Mills, G.E. (2000). Action research: A guide for the teacher researcher. Upper Saddle River, NJ: Prentice Hall, Inc.

Nowak, L.I., Miller, S.W., \& Washburn, J.H. (1996). Team testing increases performance. Journal of Education for Business, 71 (5), 253-256.

Pacanowsky, M. (1995). Team tools for wicked problems. Organizational Dynamics, 23 (3), 36-49.

Pearce, C.L., \& Conger, J.A. (2003). Shared leadership: Reframing the hows and whys of leadership. Thousand Oaks, CA: Sage Publications. 
Pearle, K.M. (2003). Intentional learning as transformational learning: The ILM and adult learners. American Educational Research Association Conference, Chicago, Illinois; April 22, 2003.

Pearle, K.M., \& Head, L. M. (2002). Using your brain to build teams at work: A study of the freshman and sophomore engineering clinics at Rowan University. American Society for Engineering Education Annual Conference \& Exposition.

Polzer, J. T. (2003 February). Leading teams. Harvard Business School Publishing. Article Reprint \#9-403-094.

Ravenscroft, S.P., \& Buckless, F.A. (1995). Incentives in student team learning: An experiment in cooperative group learning. Issues in Accounting Education,10 (1), 97-110.

Rushmer, R. (1997). What happens to the team during teambuilding? Examining the change process that helps to build a team. Journal of Management Development, 16 (5/6), 316-328.

Salas, E., Rozell, D., Mullen, B., \& Driskell, J.E., (1999), The effect of team building on performance. Small Group Research, 30 (3), 309-330.

Scudder, J.N., \& Herschel, R.T. (1994). Test of model linking cognitive motivation, assessment of alternatives, decision quality, and group process satisfaction. Small Group Research, 25 (1), 57-83.

Senge, P.M. (1990). The fifth discipline: The art and practice of the learning organization. New York: Currency Doubleday.

Senge, P.M., Cambron-McCabe, N., Lucus, T., Smith, B., Dutton, J., \& Kleiner, A. (2000). Schools That Learn: A Fifth Discipline Fieldbook for Educators, Parents, and Everyone Who Cares About Education. NY:

Doubleday.

Senge, P., Kliner, A., Roberts, C., Ross, R., \& Smith, B. (1994). The $5^{\text {th }}$ discipline fieldbook. Garden City, NY: Doubleday.

Senge, P., Kliner, A., Roberts, C., Ross, R., Roth, G., \& Smith, B. (1999). The dance of change. Garden City, NY: Doubleday.

Silverberg, R. (2003). Developing relational space: Teachers who came to understand themselves and their students as learners.. American Educational Research Association Conference, Chicago, Illinois; April 22, 2003.

Slavin, R. (1977). Classroom reward structure: An analytic and practical review. Review of Educational Research, 47 (4), 633-650. 
Slavin, R. (1999). Comprehensive approaches to cooperative learning. Theory into practice, 38 (2),_74-80.

Springer, L., Stanne, M.E., \& Donovan, S.S. (1999). Effects of small group learning on undergraduates in science, mathematics, engineering, and technology: A meta analysis. Review of Educational Research, 69 (1), 21-51.

Swezey, R.W., \& Salas, E. (1992). Teams: Their training and performance. Norwood, NJ: Ablex Publishing Corporation.

Thompson, L. (2000). Making the team: A guide for managers. Upper Saddle River, NJ: Prentice Hall, Inc.

Topping, K. (1998). Peer assessment between students in colleges and universities. Review of Educational Research, 68 (3), 249-276. 